\title{
Performance evaluation of air pollution control device at traffic intersections in Delhi
}

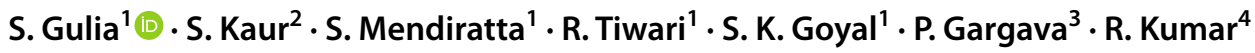

Received: 3 April 2021 / Revised: 9 June 2021 / Accepted: 30 August 2021 / Published online: 17 September 2021

(C) Islamic Azad University (IAU) 2021

\begin{abstract}
Urban air pollution and exposure-related health impacts are being noticed and discussed very intensely in India. On the other hand, source-specific control is the primary focus for policymakers; however, diverse and complex sources make it difficult to immediately see the action and consequent impacts on better air quality. Many cities across the world have witnessed high air pollution levels at traffic junctions, more so in all Indian cities. Site-specific air pollution reduction can be a promising solution for managing the pollution level at highly polluted locations. CSIR-National Environmental Engineering Research Institute, India, has designed and developed Wind Augmentation and purifYing Unit (WAYU) to remove particulate and gaseous pollutants from urban hot spots such as traffic locations. In the present study, the authors attempted to evaluate the performance of two different designs of WAYU for the removal of particulate matters from polluted air at different traffic locations in Delhi City, the national capital territory of India. The performance analyses show that the current design of WAYU removes $\mathrm{PM}_{10}$ and $\mathrm{PM}_{2.5}$ concentrations in the range of $34-49 \%$ and $19-25 \%$, respectively from the inlet air. The total PM collected from all WAYU devices was $34.19 \mathrm{~kg}$ from 120,557 operating hours' at all the sampling sites. The PM removal rate depends on the size-segregated particulate matter pollution load in the ambient air.
\end{abstract}

Keywords Vehicular pollution $\cdot$ Air purification device $\cdot$ Particulate matter $\cdot$ Efficiency $\cdot$ Physical filtration $\cdot$ Size distribution

\section{Introduction}

Elevated urban air pollution (UAP) is a major concern these days in developed and developing countries, especially at traffic junctions and roads/highways. In India, cities in northern states such as Delhi, Uttar Pradesh, Bihar and Rajasthan are facing a high level of pollution, especially during post-monsoon

Editorial responsibility: Gobinath Ravindran.

S. Gulia

s_gulia@neeri.res.in

1 CSIR-National Environmental Engineering Research Institute Delhi Zonal Centre, Naraina, New Delhi, India

2 CSIR-National Environmental Engineering Research Institute Mumbai Zonal Centre, Worli, Mumbai, India

3 Central Pollution Control Board, East Arjun Nagar, New Delhi, India

4 CSIR-National Environmental Engineering Research Institute, Nehru Marg, Nagpur, India and winter periods. These states contributed to the region's annual population-weighted mean $\mathrm{PM}_{2.5}$ in the range of $125-174 \mu \mathrm{g} \mathrm{m}^{-3}$ (WHO 2018). Earlier studies also reported (Gulia et al. 2015; Gurjar et al. 2016; Amann et al. 2017) that air quality exceed the national $\left(60 \mu \mathrm{g} \mathrm{m}^{-3} \mathrm{NAAQS}\right.$, India) and international standards (25 $\mu \mathrm{g} \mathrm{m}^{-3} \mathrm{WHO}$ ) most of the time of the year (WHO 2006). High exposure to $P M$ is linked with short-term and long-term health effects in human beings and varies as per the toxicity level of the constituting elements (Heal et al. 2012). Among the sources, emission from road transport dominates in the contribution to UAP, including particulate matter in Indian cities. Motorized vehicles generate air pollutants from the exhaust system and re-suspension of road dust due to wheel movement (Mathew et al. 2015; Goyal et al. 2019). The uneven vehicle movement within the city generates spatial variations in the pollution level and creates hotspot areas such as busy traffic intersections, roundabouts, congested narrow roads, etc. (Gokhale and Khare 2007; Gulia et al. 2019). The occurrence of a hotspot area may increase 
city's overall average pollution level, which can bring unnecessary enforcement of control actions and disturb the socioeconomic activities of the public. Therefore, it is crucial to manage the air pollution level at urban hot spots.

Globally, fourteen out of fifteen cities' air quality were found to worsen, which were from India (WHO 2018). The highest annual exposure of ambient $\mathrm{PM}_{2.5}$ was recorded in India as the population-weighted mean, i.e., $89.9 \mu \mathrm{g} \mathrm{m}^{-3}$, in the world (Lancet Planet Health 2019; Balakrishnan et al. 2019). Delhi city, where the present study was focused, is ranked one of the most polluted cities in the world in the last few years, mainly due to high pollution levels during winter and postmonsoon seasons (WHO 2018). The pollutant concentrations reached alarming levels at some of the locations and were found 3-5 times higher than prescribed levels (NAAQS). Numerous studies have been conducted on air pollution in Delhi, considering source apportionment, control strategies and estimation of associated health impacts (Gupta and Kumar 2006; CPCB 2010; Gupta et al. 2010; Kumar et al. 2017; TERI 2018). In one of the studies, Guttikunda and Goel (2013) observed that one-third $\mathrm{PM}_{10}$ emission is generated by re-suspension of dust; however, vehicle exhaust emission contributed up to $45 \%$ of total $\mathrm{PM}_{2.5}$ emissions. The problem worsens during winter when PM's dispersion becomes very low and particles started to coagulate due to moisture (Guttikunda and Gurjar 2012). In terms of load, Sharma and Dikshit (2015) have estimated that approximately 12.9 Ton/day and 11.6 Ton/day, of $\mathrm{PM}_{10}$ and $\mathrm{PM}_{2.5}$, respectively, are emitted from in-use road vehicles in Delhi city. Total registered vehicles in Delhi were 11.2 million in 2018 with a cumulative annual growth rate of $~ 7 \%$ (MoSPI 2018). This indicates that air quality in urban areas is getting deteriorated due to vehicular emission significantly.

Given the problem of high air pollution, air quality managers introduced numerous strategies in the city to mitigate air pollution from vehicles. Some of them are also shifting of fuel from diesel to $\mathrm{CNG}$, odd-even number-based vehicle movement, restriction on entry of heavy diesel vehicles during the day time, banning of diesel vehicles of age more than 10 years, phasing out 15-year-old vehicles from roads, improvement in PUC (Pollution Under Control tests for idling vehicles) program, the introduction of BS-VI fuel (Dholakia et al. 2013; Gulia et al. 2017; Kumar et al. 2017). All these strategies are implemented throughout the city and impacted the public's socioeconomic status throughout the city, including those places also where pollution level within the specified limit. The quantification of their positive impact on air pollution is challenging due to inadequate infrastructure for effective implementation and tracking. Further, the implementation of such control actions requires strict enforcement, a post-implementation monitoring plan and public support, which could be one of the major challenges for their success.

Some of the improvements observed in the air quality compared to last year have been due to the restriction of source-specific activities during the lockdown period in 2020 due to Covid-19. The complete lockdown was implemented from March 25, 2020 to April 20, 2020 and then phase-wise unlock of lockdown initiated by Government. Past studies revealed significant PM reduction during the lockdown period in India (Jain and Sharma 2020; Sharma et al. 2020; Kumar et al. 2020). There were almost no vehicles on the road, no industrial activities, no street tandoors and closed restaurants/malls. This brought a reduction of $\mathrm{PM}_{2.5}$ and $\mathrm{PM}_{10}$ in Delhi during the Lockdown period by $~ 41 \%\left(66-39 \mu \mathrm{g} \mathrm{m}^{-3}\right)$ and $\sim 52 \%$ (153-73 $\mu \mathrm{g} \mathrm{m}^{-3}$ ), respectively (Jain and Sharma 2020). A similar observation was found by other researchers as well (Sharma et al. 2020; Kumar et al. 2020). The data indicate that despite severe restrictions within the city, the actual reduction was about half of the earlier pollution level.

Regulators and concerned stakeholders have started thinking about the removal of pollutants from ambient air along with control measures at source from the last few years. Multiple debates have been initiated for the installation and testing of a giant air purifier (smog tower) in Xian city of China. However, no scientific study has been done so far on the performance of this giant air purifier (smog towers) in the public domain. Parallel to this, researchers started work on ambient air purifier design in different parts of the world using scientific methods of biofiltration, phytoremediation, filtration, ionization and photocatalytic oxidation (Liu et al. 2015; Januszkiewicz and Kowalski 2019; Gulia et al. 2020). The efficiency of these scientific methods varies by pollutant such as ionization and physical filtration can remove PM in the range of $61-95 \%$ and $\sim 70 \%$, respectively, while phytoremediation can remove in the range of $24-40 \%$. The phytoremediation can remove NO $x$ in the range of $10-15 \%$ (Gulia et al. 2020). CSIR-National Environmental Engineering Research Institute (NEERI) has started work in this area and designed an ambient air purification system and tested its performance at different traffic locations in Delhi city. The present article provides the findings of the performance evaluation analysis of two different designs of Wind Augmentation Purifying Unit (WAYU) installed at different traffic intersection areas in Delhi city. The study focuses on: (1) performance evaluation of two different design of air purification devices for $\mathrm{PM}$, i.e., $\mathrm{S}$ shape (with flow rate $1250 \mathrm{~m}^{3} \mathrm{~h}^{-1}$ and 2500 
$\mathrm{m}^{3} \mathrm{~h}^{-1}$ ) and Mushroom shape (Flow rate $2500 \mathrm{~m}^{3} \mathrm{~h}^{-1}$ ); and (2) performance of devices with respect to sites which have varying pollution load and particle size distribution. The study was carried out during November 2018 to June 2019.

\section{Materials and methods}

\section{Selection of study sites}

Delhi is the capital territory of India and has a population of 22.2 million in the year 2011 over an area of $1483 \mathrm{~km}^{2}$ (Census 2011) and is estimated to be increased up to 30.0 million in 2020. With more than 11 million registered in the year 2018 moving on 33,198 $\mathrm{km}$ road length and 1282 traffic intersections, Delhi's arterial roads are too congested during peak hours. A total of five locations were selected to install the WAYU devices with criteria of high traffic density, busy/congested road, high business activity area, etc. The performance of devices was tested at Anand Vihar (East Delhi), ITO Intersection (Central Delhi), Shadipur (Central Delhi) Wazirpur Chowk (Northwest) and Bhikaji Cama Place (South Delhi). The site details, including land use feature, traffic density, road condition and pollution level from nearest continuous ambient air quality monitoring station (CAAQMS), are given in Table 1 and are shown on each site's google map view in Fig. 1. In addition to these parameters, the

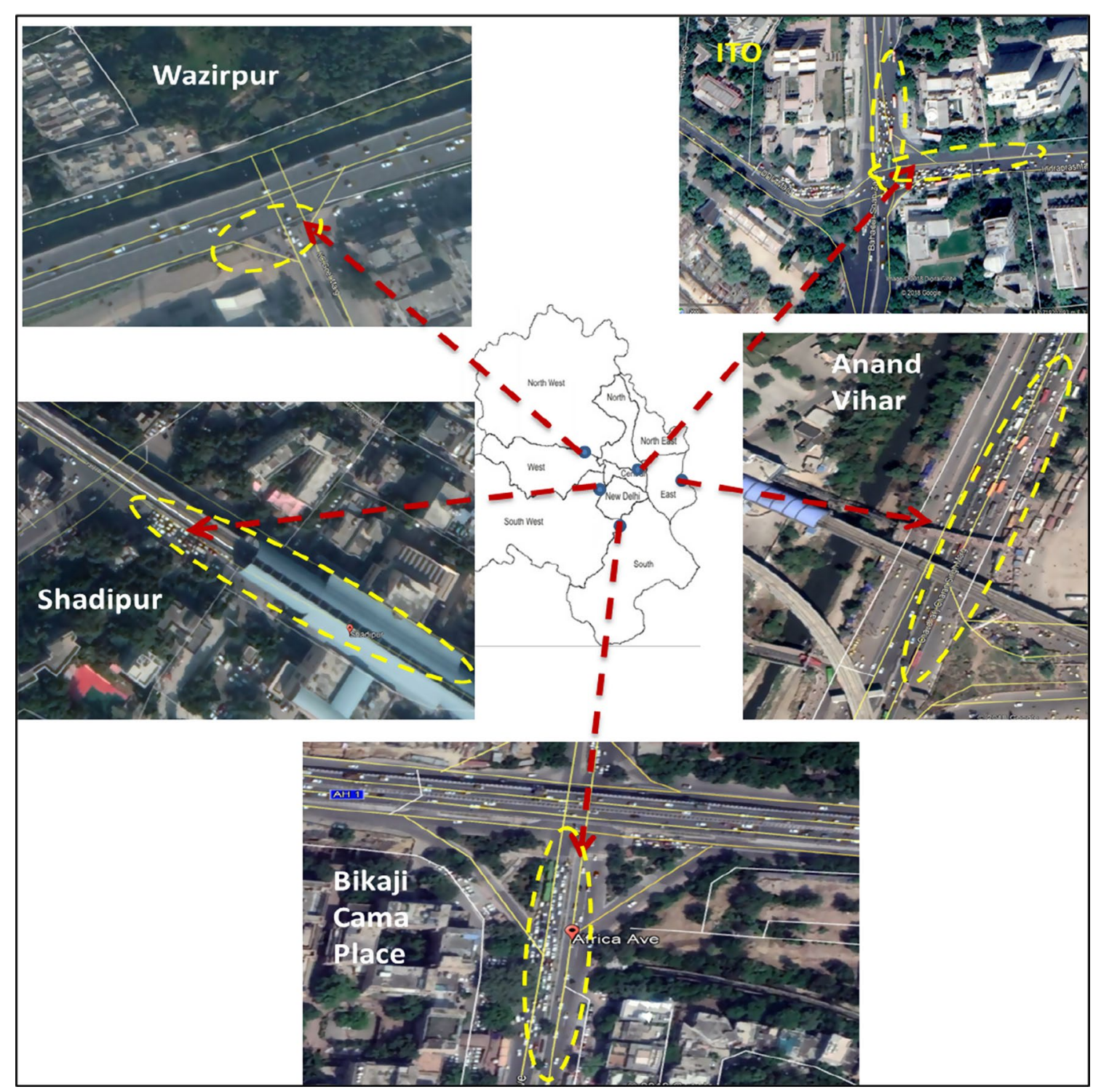

Fig. 1 Google view of five study sites showing road feature and congested traffic lane 


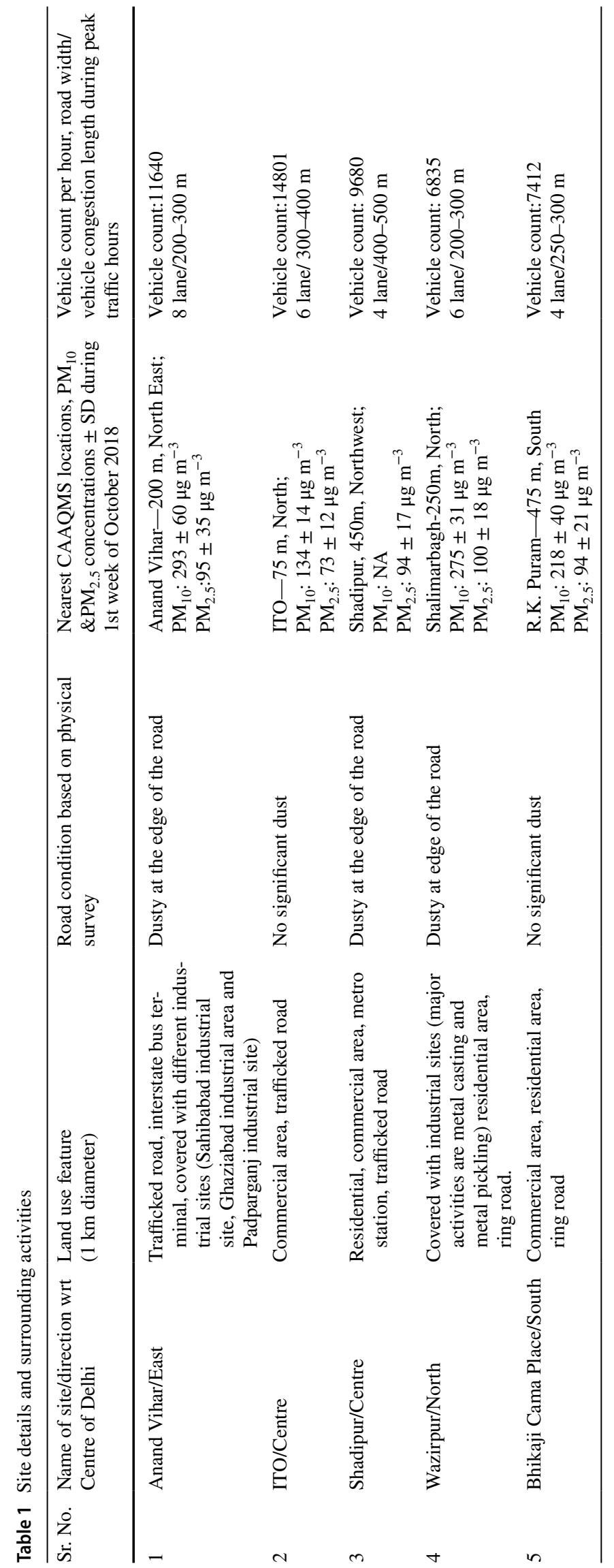


feasibility of the installation of WAYU is also one of the criteria for selecting sites for the testing of the device.

All five sites experience severe congestions during traffic peak hours, especially near traffic junctions. The idling conditions and slow movement of vehicles generate more pollution and form episodic condition. The road condition was found dusty (dust observed on the edge of the road) at Anand Vihar, Shadipur and Wazirpur compared to ITO and Bhikaji Cama place road site. The average $\mathrm{PM}_{10}$ concentrations were found in the range of 134 (ITO) - $300 \mathrm{\mu g} \mathrm{m}^{-3}$ (Anand Vihar) which might be due to the contribution of local activities and traffic emission and road dust re-suspension. However, not much change was found in $\mathrm{PM}_{2.5}$ level concentrations at sites and ranged between 73 and $100 \mu \mathrm{g} \mathrm{m}^{-3}$. Further, the pictorial view and traffic pattern maps of Google showing traffic congestions at each selected site are shown in Figs S1 \& S2 of Supplementary Information (SI).

\section{Working Principle and Technical Specification of WAYU design}

The journey of WAYU started with a fundamental design having high space requirement and low throughput in the year 2017, which was improved later in terms of different shapes ("S" \& Mushroom), throughput and filter material, as shown in Fig. 2. WAYU uses high-speed wind generators having a flow rate of 1250 and $2500 \mathrm{~m}^{3} \mathrm{~h}^{-1}$. The filter material used is non-woven fabric having a long operation cycle and reasonable efficiency for $\mathrm{PM}_{10}$ and $\mathrm{PM}_{2.5}$. Non-woven fabrics are bonded together by entangling fiber or filaments. The size of the filter used is $50 \mathrm{~cm} \times 51 \mathrm{~cm}(L \times W)$ for $\mathrm{S}$ shape and $28 \mathrm{~cm} \times 21 \mathrm{~cm}$

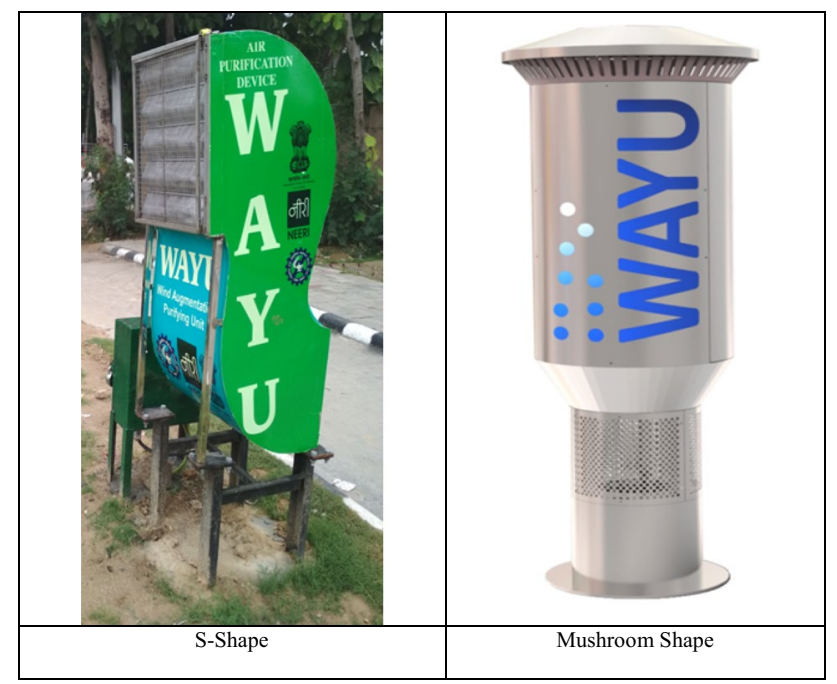

Fig. 2 Photographs of WAYU—a S shape design, b Mushroom shape design of each of three filters in Mushroom design. The filter material is sandwiched between high-density poly ethylene (HDPE) mesh. The deposition of particles on filter media reduces the pore size, which enhances pressure drop at the outlet and ultimately reduces the CADR values of the device. The initial pressure drop for the filter used is $2.5 \mathrm{mmWG}$. However, it was found that pressure drop continuously increased as the filter exposed to polluted air during operation at the field. The pressure drop reached up to $50 \%$ on the 6th day at Anand Vihar and 7 th day at ITO which is due to the high particle load in the ambient air during winter. These values during the post-monsoon period (high pollution episode) are the 3rd day at Anand Vihar and the 5th day at ITO, respectively. These filters show $\mathrm{PM}_{10}$ removal efficiency by 90\% which is equal to EURO 3 filters. The PM removal efficiency of these filters was tested in the laboratory as per BS-2831. The detailed specifications of both the design are given in SI, Table S1. The device also has a photocatalyst to oxidize the CO and VOCs in smaller non-polluting compounds. The air is passed through the filters where different size fractions of PM $\left(\mathrm{PM}_{10}\right.$ and $\mathrm{PM}_{2.5}$ ) are trapped on filters. The device generates clean air from the outlet with force and develops turbulence in the near field area and dilutes the pollution level (CPCB 2018). In Mushroom shape, the inlet height is 3 $\mathrm{ft}(\sim 1 \mathrm{~m})$ from the base on the device and in $\mathrm{S}$ shape, it is $5 \mathrm{ft}$ from the ground. The devices are mounted on a concrete platform for safety and stability purposes. The noise level generated from the motor installed in S-shape and Mushroom-shape design varies from $50-55 \mathrm{~dB}$ and 60-65 dB, respectively, as per manufacturers specification. The noise generated by vehicular movement predominates at traffic site and suppresses the noise generated by the device. The operational cost of the device comprising electricity cost, human resources cost for filter replacement, transport cost for filter change and maintenance cost varies based on the total number of device operations, number of sites and distance between locations. In the present study of 54 devices operation at five sites for $15 \mathrm{~h}$ per day and replacement of filter on weekly basis, the operation and maintenance cost of a device was $\sim 3500$ per month.

\section{Methodology adopted for performance evaluation}

The methodology adopted to evaluate the WAYU device's performance and its operation protocol is described in SI Fig. S3 in the form of a process flowchart. Each device was operated for $15 \mathrm{~h}$ in a day starting from $06: 00 \mathrm{~h}$ to 22:00 h with a 01-h break from 14:00 to $15: 00 \mathrm{~h}$, which includes morning and evening peak traffic hours. Each 
device has an automatic power control timer for operation. Devices were kept switch off during the rainy season and power failure. There is a requirement of regular filter change from each device and replaces it with a new filter. The frequency of the filter change was decided based on the pressure drop. Further, a device's performance was evaluated in two different ways, viz. dust collection rate and by comparing PM concentration at inlet and outlet of the device. The exposed filters were brought back to the laboratory, where it was weighed using a $0.002 \mathrm{~g}-20 \mathrm{~kg}$ weighing scale, smart electronic weighing scale of Accurate Electronics Aqua Precision.

The PM weight was calculated for each device using Eq. (1) and concentration removal by Eq. (2).

$\mathrm{PM}_{r}=\frac{W_{e}-W_{f}}{N}$

$\mathrm{PM}_{\mathrm{c}} \frac{\mathrm{PM}_{r}}{F} * 10^{6}$

where $\mathrm{PM}_{\mathrm{r}}$ stands for PM mass collection rate $\left(\mathrm{g} \mathrm{hr}^{-1}\right)$, " $\mathrm{W}_{\mathrm{e}}$ " stands for the weight of exposed filter $(\mathrm{g})$, " $\mathrm{W}_{\mathrm{f}}$ " stands for weight for the fresh filter (g), N stands for the number of operating hour between filter change, $\mathrm{PM}_{\mathrm{c}}$ stands for PM concentration removal, and " $F$ " stands for device average flow rate (average for operational days) which is $807 \mathrm{~m}^{3} \mathrm{~h}^{-1}$ (design flow $1250 \mathrm{~m}^{3} \mathrm{~h}^{-1}$ ) and 1650 $\mathrm{m}^{3} \mathrm{~h}^{-1}$ (design flow rate $2500 \mathrm{~m}^{3} \mathrm{~h}^{-1}$ ) for $\mathrm{S}$ shape and $1816 \mathrm{~m}^{3} \mathrm{~h}^{-1}$ (design value $2500 \mathrm{~m}^{3} \mathrm{~h}^{-1}$ ) for Mushroom design.

Each filter was cleaned through a vacuum system followed by washing. The dust collected from each site was stored separately every month and analyzed for particle size distribution and heavy metal contents. The PM monitoring at the inlet and outlet of the device was carried out using R-11 model of Aerosol Monitor (GRIMM, 2020).

\section{Results and discussion}

\section{PM mass collection rate by WAYU}

The total PM mass collected during the study period from all devices was $34.19 \mathrm{~kg}$ from a total of 120,557 operating hours (sum of all devices at five sites). The average dust collection rate was $0.36 \mathrm{~g} \mathrm{~h}^{-1}$ device ${ }^{-1}$ during postmonsoon and winter seasons and $0.26 \mathrm{~g} \mathrm{~h}^{-1}$ device $^{-1}$ during the summer season (Table 2). Similarly, the average $\mathrm{PM}$ concentration removal rate was $181 \mathrm{\mu g} \mathrm{m}^{-3}$ during the post-monsoon and winter period and $123 \mu \mathrm{g} \mathrm{m}^{-3}$ during the summer from $1 \mathrm{~m}^{3}$ of polluted air passed through device. This indicates that the device performs more efficiently when pollution loads higher during the postmonsoon and winter in comparison with summer period. The PM collection rate varies from site to site, which is based on pollution load and particle size distribution. The average PM collection rates at different sites by devices were found as $0.31-0.60 \mathrm{~g} \mathrm{~h}^{-1}, 0.10-0.23 \mathrm{~g} \mathrm{~h}^{-1}$, $0.17-0.42 \mathrm{~g} \mathrm{~h}^{-1}, 0.33-0.62 \mathrm{~g} \mathrm{~h}^{-1}$ and $0.14-0.30 \mathrm{~g} \mathrm{~h}^{-1}$ at Anand Vihar, ITO, Shadipur, Wazirpur Chowk and Bhikaji Cama Place, respectively. It is also observed that PM collection rate by Mushroom design was found higher than S-shape design at a particular site except at Wazirpur site, which might be due to different influences of road dust re-suspension at Mushroom and S-shape devices. Further, the clean air delivery rate (CADR) of WAYU varies as per pollution load in the ambient air and capacity of the devices and found in the range of $191-584 \mathrm{~m}^{3} \mathrm{~h}^{-1}$ which is minimum at Shadipur for $\mathrm{S}$-shape device $\left(1250 \mathrm{~m}^{3} \mathrm{~h}^{-1}\right.$ capacity) and maximum at Anand Vihar for S-shape device $\left(2500 \mathrm{~m}^{3} \mathrm{~h}^{-1}\right)$. At Wazirpur, both designs are of the same capacity, i.e., $2500 \mathrm{~m}^{3} \mathrm{~h}^{-1}$, and indicates more or less similar CADR, i.e., $426-472 \mathrm{~m}^{3} \mathrm{~h}^{-1}$. In general, the Mushroom shape device performs more efficiently as it has a higher filter area and compact shape. The total air passed by WAYU devices was 225.85 million $\mathrm{m}^{3}$ during the whole study period. It is also observed that a high throughput design device collects more dust than a low throughput device.

The deposition of PM on filters reduced the flow of air and many times choked filters, especially during the episodic condition, which further reduced the pore size of the results of the filter into pressure drop at the outlet. Airflow at the outlet of different capacity devices was measured daily up to 5th day. The flow rate and pressure drop were checked at the outlet of the device. It was observed that at Anand Vihar, the flow rate was reduced to half on the third day after the change of fresh filter during November 2018. However, it was reduced to half on the fifth day at ITO intersection during the same period. The PM level was high at Anand Vihar as compared to ITO and, accordingly, dusts deposition rates on the filter. Therefore, filters were changed at an interval for 3 days at ITO and Anand Vihar sites extending up to 7 days during winter and summer.

\section{Particle size distribution analysis of collected dust}

The selected samples of collected dust by WAYU device were analyzed for particle size distribution (PSD) using a Malvern analyzer. The average cumulative distribution patterns of each site are shown in SI Table S2 and Fig. 3. The differentiated volumes of size-segregated particles are presented in supplementary information as Fig. S4. 
Table 2 Site-wise details of PM mass collection by WAYU System

\begin{tabular}{|c|c|c|c|c|c|c|c|c|c|}
\hline \multirow[t]{2}{*}{ S. No. } & \multirow{2}{*}{$\begin{array}{l}\text { Locations } \\
\text { (no. of } \\
\text { devices) }\end{array}$} & \multirow{2}{*}{$\begin{array}{l}\text { No. of device } \\
\text { (s) (Flow } \\
\text { rate) }\end{array}$} & \multirow{2}{*}{$\begin{array}{l}\mathrm{CADR}^{\$} \\
\mathrm{~m}^{3} \mathrm{~h}^{-1}\end{array}$} & \multicolumn{3}{|c|}{ Post-monsoon and winter Period } & \multicolumn{3}{|c|}{ Summer season } \\
\hline & & & & $\begin{array}{l}\text { Total PM } \\
\text { collected } \\
(\mathrm{g})\end{array}$ & $\begin{array}{l}\text { Collection rate } \\
\left(\mathrm{g} \mathrm{h}^{-1} \text { device }^{-1}\right)\end{array}$ & $\begin{array}{l}\text { PM mass } \\
\text { collection } \\
(\mu \mathrm{g}) \text { per } \mathrm{m}^{3} \\
\text { of air passed } \\
\text { through each } \\
\text { device }\end{array}$ & $\begin{array}{l}\text { Total PM } \\
\text { collected } \\
(\mathrm{g})\end{array}$ & $\begin{array}{l}\text { Collection } \\
\text { rate }\left(\mathrm{g} \mathrm{h}^{-1}\right)\end{array}$ & $\begin{array}{l}\text { PM mass col- } \\
\text { lection }(\mu \mathrm{g}) \\
\text { per } \mathrm{m}^{3} \text { of air } \\
\text { passed through } \\
\text { each device }\end{array}$ \\
\hline 1 & $\begin{array}{l}\text { Anand Vihar } \\
(10)(4 \\
\text { Novem- } \\
\text { ber18-4 } \\
\text { June19) }\end{array}$ & $\begin{array}{c}\text { 03-S: } 1250 \\
\mathrm{~m}^{3} \mathrm{~h}^{-1} \\
07-\mathrm{S}: 2500 \\
\left.\mathrm{~m}^{3} \mathrm{~h}^{-1}\right)\end{array}$ & $\begin{array}{l}381 \\
584\end{array}$ & 9372 & 0.60 & 444 & 3911 & 0.31 & 221 \\
\hline \multirow[t]{2}{*}{2} & $\begin{array}{l}\text { ITO-CPCB } \\
(13)(5 \\
\text { Novem- } \\
\text { ber } 18-4 \\
\text { June19) }\end{array}$ & $\begin{array}{c}\text { 11-S: } 1250 \\
\mathrm{~m}^{3} \mathrm{~h}^{-1}\end{array}$ & 405 & 2829 & 0.18 & 226 & 1327 & 0.10 & 105 \\
\hline & & $\begin{array}{c}2 \text {-M: } 2500 \\
\mathrm{~m}^{3} \mathrm{~h}^{-1}\end{array}$ & 656 & 129 & 0.23 & 124 & 488 & 0.18 & 99 \\
\hline \multirow[t]{2}{*}{3} & $\begin{array}{l}\text { Shadipur (11) } \\
\text { (6 Decem- } \\
\text { ber18-4 } \\
\text { June19) }\end{array}$ & $\begin{array}{c}\text { 5-S: } 1250 \\
\mathrm{~m}^{3} \mathrm{~h}^{-1}\end{array}$ & 191 & 1229 & 0.20 & 252 & 1035 & 0.17 & 206 \\
\hline & & $\begin{array}{c}\text { 6-M: } 2500 \\
\mathrm{~m}^{3} \mathrm{~h}^{-1}\end{array}$ & 517 & 2043 & 0.42 & 231 & 2220 & 0.30 & 164 \\
\hline \multirow[t]{2}{*}{4} & $\begin{array}{l}\text { Wazirpur (7) } \\
\text { (11 Decem- } \\
\text { ber18-4 } \\
\text { June19) }\end{array}$ & $\begin{array}{c}\text { 4-S: } 2500 \\
\mathrm{~m}^{3} \mathrm{~h}^{-1}\end{array}$ & 472 & 1828 & 0.62 & 373 & 2148 & 0.58 & 352 \\
\hline & & $\begin{array}{c}\text { 3-M: } 2500 \\
\mathrm{~m}^{3} \mathrm{~h}^{-1}\end{array}$ & 426 & 496 & 0.40 & 222 & 1147 & 0.33 & 184 \\
\hline \multirow[t]{2}{*}{5} & $\begin{array}{l}\text { Bhikaji Cama } \\
\text { (13) (04 } \\
\text { February }-4 \\
\text { June 19) }\end{array}$ & $\begin{array}{c}\text { 5-S: } 1250 \\
\mathrm{~m}^{3} \mathrm{~h}^{-1}\end{array}$ & 291 & 559 & 0.30 & 373 & 793 & 0.14 & 177 \\
\hline & & $\begin{array}{c}\text { 8-M: } 2500 \\
\mathrm{~m}^{3} \mathrm{~h}^{-1}\end{array}$ & 395 & 771 & 0.30 & 164 & 2058 & 0.24 & 129 \\
\hline Total & & & $191-656$ & 19256 & $0.36^{*}$ & $267 *$ & 15127 & $0.26^{*}$ & $182 *$ \\
\hline
\end{tabular}

"S"-S shape, M-Mushroom shape

\# No operating hours were excluded from the analysis

*Average flow rate for operational period

$\$ C A D R$ is calculated using the average flow rate of WAYU during the operation period

At ITO, the portion of particles having size 2.5 and $10 \mu \mathrm{m}$ was found in the range of $4.9-17 \%$ and $29-57 \%$, respectively; however, these values at Anand Vihar were found in the range of $6.8-7.8 \%$ and $45-51 \%$, respectively. There are huge variations in the PSD at ITO and Anand Vihar sites when compared with different time samples. At Shadipur, Wazirpur and Bhikaji Cama Place, the portion of particles having size 2.5 and $10 \mu \mathrm{m}$ was found to be $8.5-9.5 \% 36.8-48.9 \%$, respectively, $7.8-10.8 \%$ and $36.8-48 \%$, respectively, and $9.6-10.2 \%$ and $40.7-45.3 \%$, respectively. It is inferred that PSD at ITO is different from the other four sites, which might be due to the contribution of PM's surrounding sources. For example, Anand Vihar and Wazirpur sites are influenced by industrial emissions and traffic being surrounded by Industrial areas; however, the Shadipur site is influenced by the resuspension of road dust, which generates coarser particle. At ITO, the proportion of $\mathrm{PM}_{2.5}$ particles were found up to $17 \%$, while at another site, it was only up to $10 \%$. 
Fig. 3 Average cumulative plots of PSD analysis result at different sites

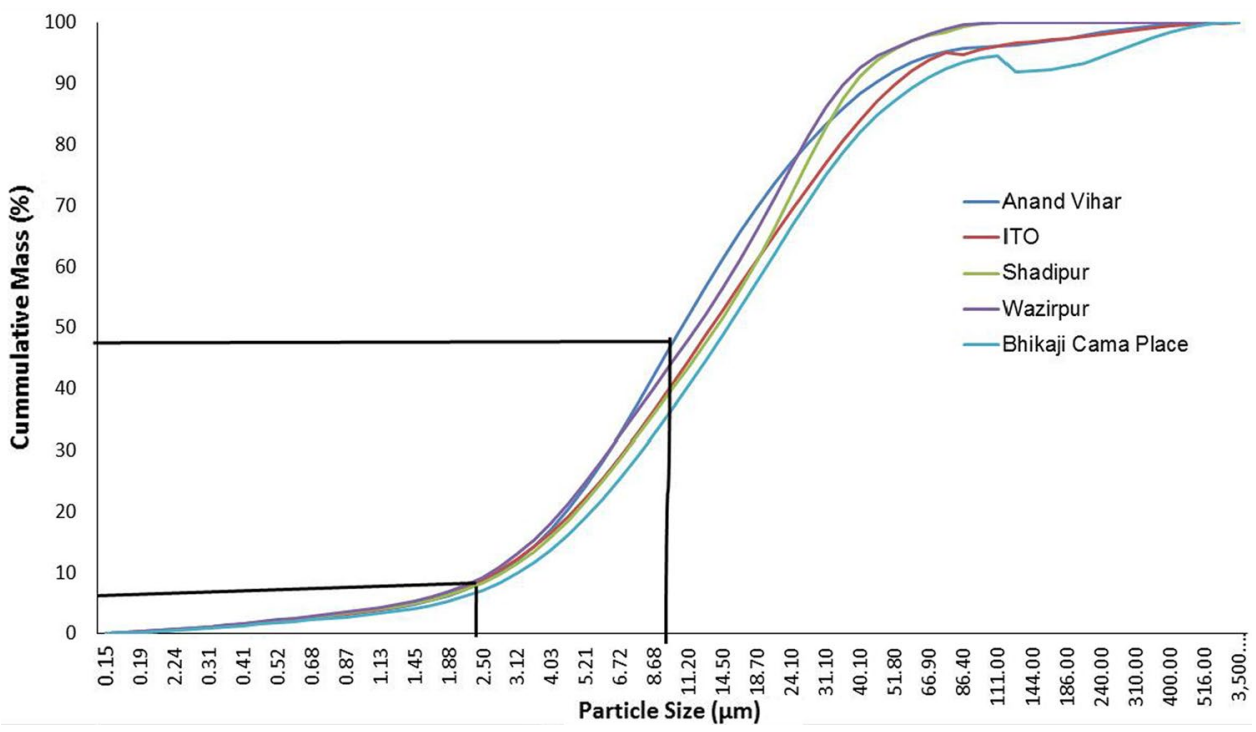

\begin{tabular}{|c|c|c|c|c|c|}
\hline \multirow[t]{3}{*}{ Device design } & \multirow[t]{3}{*}{ Parameters } & \multicolumn{4}{|c|}{$\begin{array}{l}\text { Percentage difference of } \mathrm{PM}_{10} \text { and } \mathrm{PM}_{2.5} \text { concen- } \\
\text { tration at inlet and outlet of the device }\end{array}$} \\
\hline & & \multicolumn{2}{|l|}{ Anand Vihar } & \multicolumn{2}{|l|}{ ITO } \\
\hline & & $\mathrm{PM}_{10}$ & $\mathrm{PM}_{2.5}$ & $\mathrm{PM}_{10}$ & $\mathrm{PM}_{2.5}$ \\
\hline Design of device & Nos. of reading/ flow rate & 22 & 22 & 23 & 23 \\
\hline S Shape & $\left(1250 \mathrm{~m}^{3} \mathrm{~h}^{-1}\right)$ & $34-40$ & $19-25$ & $45-49$ & $19-20$ \\
\hline S Shape & $\left(2500 \mathrm{~m}^{3} \mathrm{~h}^{-1}\right)$ & $37-41$ & $18-23$ & NA & NA \\
\hline Mushroom shape & $\left(2500 \mathrm{~m}^{3} \mathrm{~h}^{-1}\right)$ & NA & NA & $32-36$ & $18-24$ \\
\hline
\end{tabular}

NA means, design of devices not installed at a particular site
Table 3 Summary of performance evaluation of different capacity and types of WAYU at two sites in Delhi

\section{PM removal efficiency of WAYU}

The PM monitoring is carried out for two sites only, i.e., ITO and Anand Vihar, where both designs of WAYU are installed. The monitoring results of $\mathrm{PM}_{10}$ and $\mathrm{PM}_{2.5}$ concentrations at the inlet and outlet of the device having a fresh and exposed filter during post-monsoon and winter seasons are given in Table 3. PM monitoring was not carried out during the summer season. The PM monitoring was done for the installed S-shape WAYU device at the site having a flow rate of $1250 \mathrm{~m}^{3} \mathrm{~h}^{-1}$.

The average removal efficiency of $\mathrm{PM}_{10}$ for the device with the exposed filter was found to be $45-49 \%$ range, whereas $\mathrm{PM}_{2.5}$ was found to be $19-20 \%$ at the ITO intersection. ITO site is majorly covered with commercial activities with higher traffic intensity during peak hours. The efficiency of Mushroom shape at ITO was found to be $32-36 \%$ for $\mathrm{PM}_{10}$ and $18-24 \%$ for $\mathrm{PM}_{2.5}$. The efficiency of collecting $\mathrm{PM}_{2.5}$ particles was quite similar for both devices (S-shape and Mushroom) while for $\mathrm{PM}_{10}$ efficiency of S-shape devices was found higher ( 15\%) in comparison with Mushroom shape devices. At Anand Vihar, two different capacities of devices were operated having a flow rate of $1250 \mathrm{~m}^{3} \mathrm{~h}^{-1}$ and $2500 \mathrm{~m}^{3} / \mathrm{h}$. For WAYU of $1250 \mathrm{~m}^{3} \mathrm{~h}^{-1}$, the average removal efficiency of $\mathrm{PM}_{10}$ and $\mathrm{PM}_{2.5}$ was $34-40 \%$ and $19-25 \%$, respectively. These values for the higher-capacity device (2500 $\mathrm{m}^{3} \mathrm{~h}^{-1}$ ) were $37-41 \%$ for $\mathrm{PM}_{10}$ and $18-23 \%$ for $\mathrm{PM}_{2.5}$. From the results, it was found that efficiency for both devices (flow rate $1250 \mathrm{~m}^{3} \mathrm{~h}^{-1}$ and $2500 \mathrm{~m}^{3} \mathrm{~h}^{-1}$ ) was the same as filter media is the same. The removal efficiency of $\mathrm{PM}_{10}$ particles was higher $(\sim 20 \%)$ in comparison with $\mathrm{PM}_{2.5}$.

Further, the particle size distribution in ambient air at inlet and outlet of devices is analyzed using Aerosol Monitor of GRIMM make (GRIMM 2020) having 31 channel of particle size. It is observed that the reduction in ultrafine particle (size $<01 \mu \mathrm{m}$ ) was very less, i.e., $2 \%$ each at ITO and Anand Vihar site while their proportion in overall mass were $33 \%$ and $14 \%$, respectively. These 

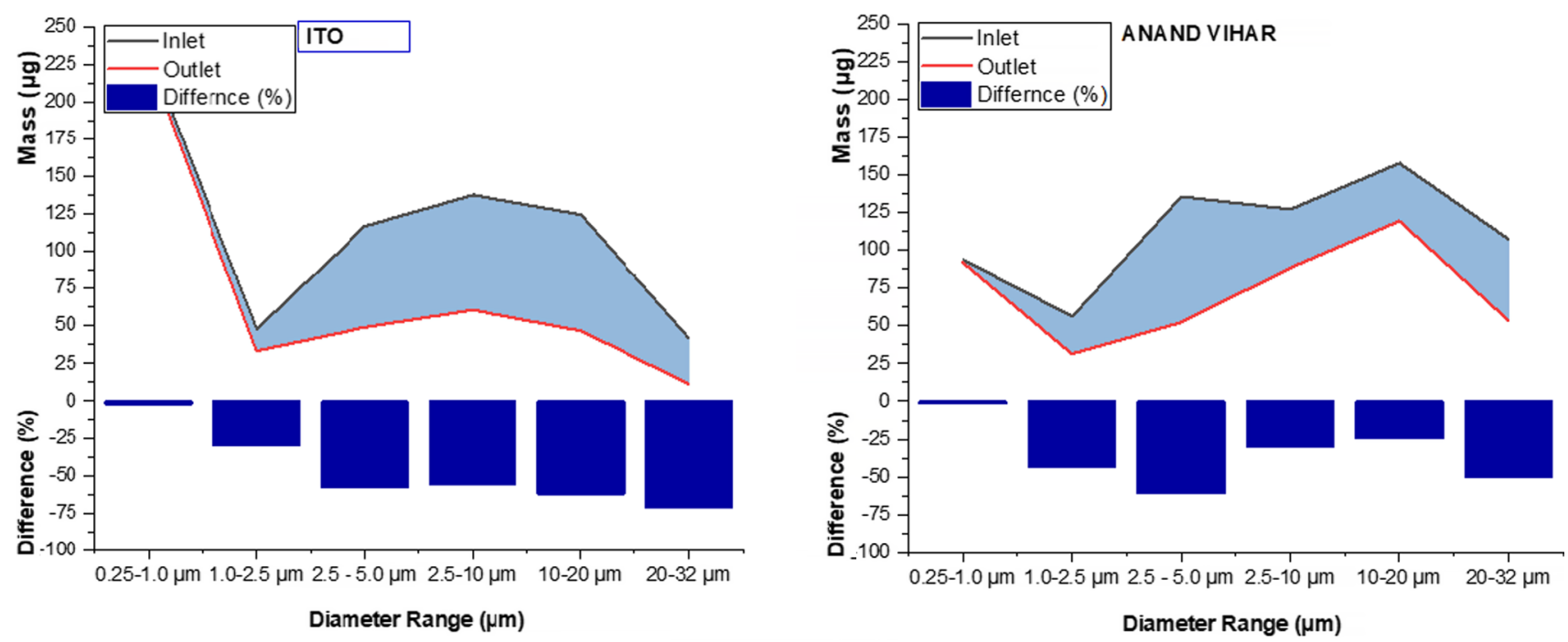

Fig.4 Size-segregated particles size mass at inlet and outlet of device and their percentage difference at ITO and Anand Vihar sites

reduction percentages of particle size range 1.0-2.0 $\mu \mathrm{m}$ were $30 \%$ and $44 \%$, respectively, while their overall mass contribution was $7-8 \%$ at each location. Further, the reduction percentage of particle size range $2.5-10 \mu \mathrm{m}$ was $57 \%$ and $19 \%$ at ITO and Anand Vihar site, respectively, and their mass proportion were $36 \%$ and $39 \%$, respectively, which is significant. These devices need to be improved for the removal of ultrafine particles which are the dominant proportion of mass from overall distribution at traffic sites. However, the devices are most suitable for a particle size range of $2.5 \mu \mathrm{m}$ to $10 \mu \mathrm{m}$ whose percentage at traffic location is significant and accordingly reduction percentage (Fig. 4). It is also noted that the profile of different sized particles at traffic sites influences the overall performance of the device in the reduction of particulate matter concentrations.

\section{Comparison of ambient $\mathrm{PM}_{10}$ level of nearest CAAQMS and PM Collection Rate by WAYU}

Further, PM collection rate $(\mathrm{g} / \mathrm{hr})$ by WAYU was compared with PM concentration monitored by CAAQMS located near the site (Figs. 5, 6). The PM collection rates by a device were found directly proportional to the ambient PM concentration. In comparing both sites, the collection rate was higher at Anand Vihar compared to ITO site.

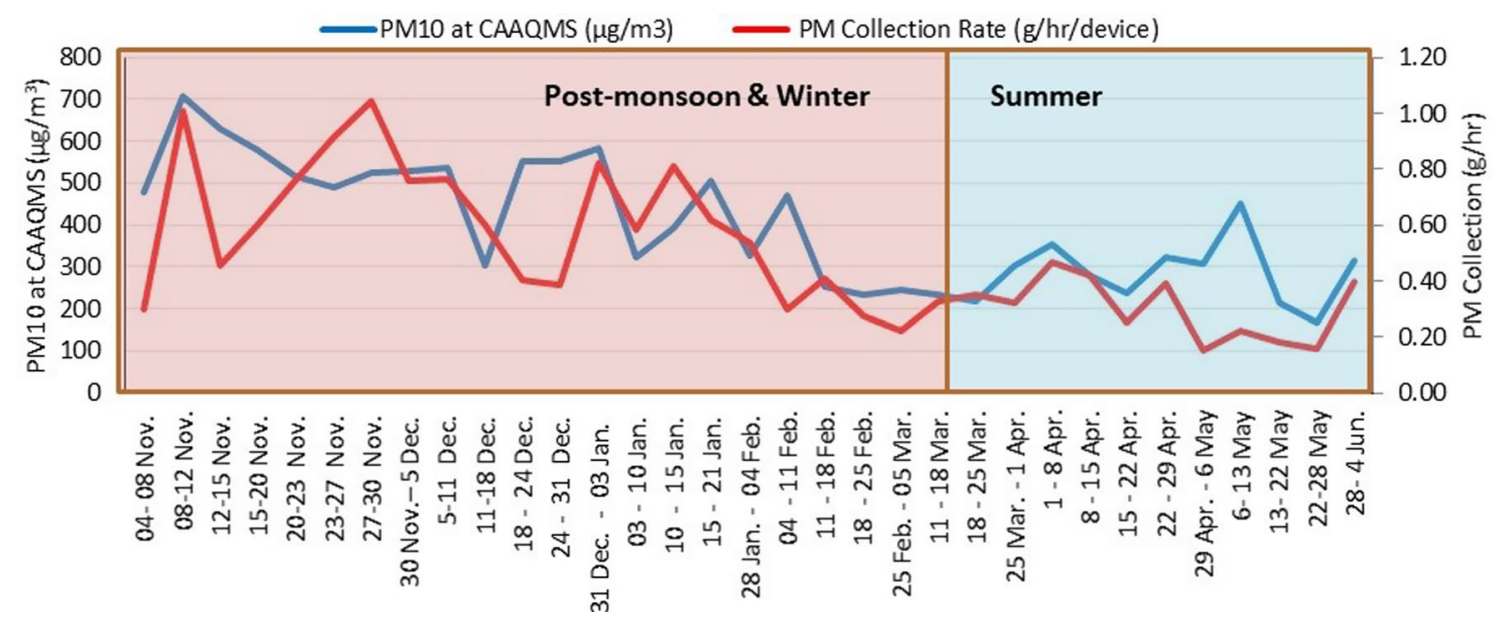

Fig. 5 Comparison of ambient $\mathrm{PM}_{10}$ concentration and PM collection rate at Anand Vihar 


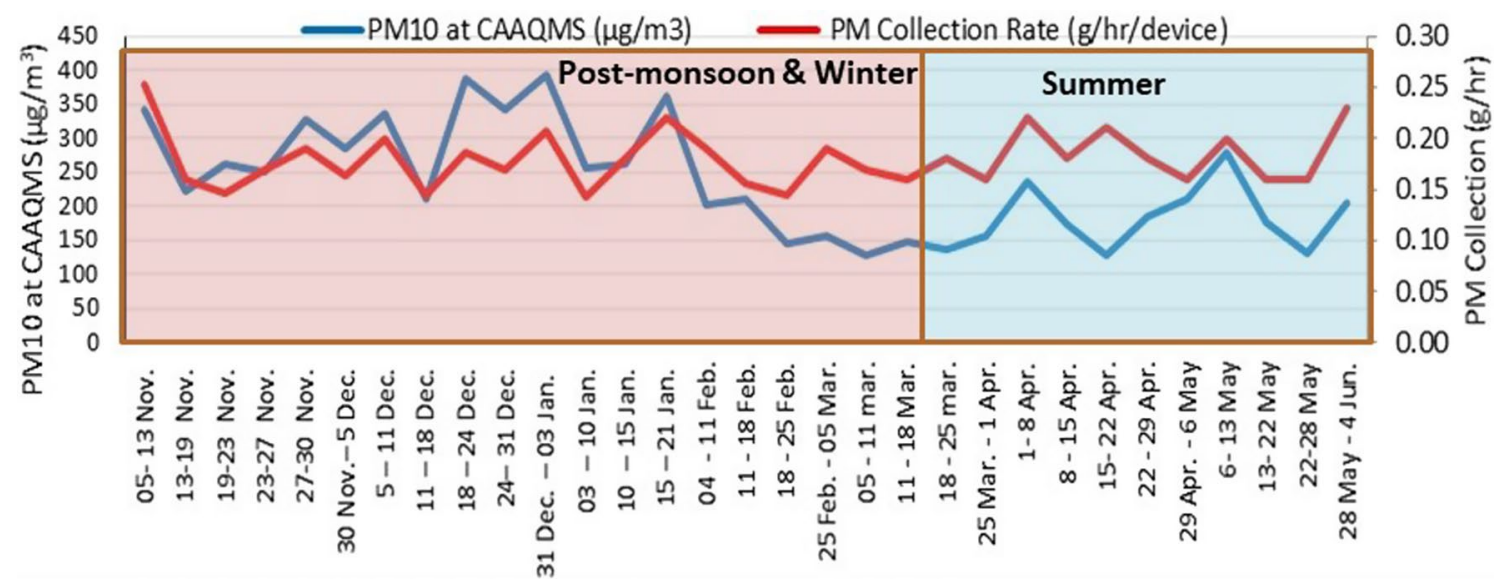

Fig. 6 Comparison of ambient $\mathrm{PM}_{10}$ concentration and PM collection rate at ITO

\section{Conclusion}

The present pilot study was an attempt to evaluate the performance of small-scale air purification devices at different traffic locations/polluted sites in Delhi city. The findings of the study are summarized as follows:

- The total PM collected from all WAYUs was $34.19 \mathrm{~kg}$ from a total of 120,557 operating hours (sum of all devices at five sites). The PM mass removal rate was observed to be $267 \mu \mathrm{g}$ in $1 \mathrm{~m}^{3}$ air passed from the device (124-444 $\mu \mathrm{g}$ in $\mathrm{m}^{3}$ of air passed). The CADR varies in the range of $191-656 \mathrm{~m}^{3} \mathrm{~h}^{-1}$ which is due to different pollution loads at sites and different designs and capacities of the device at the same site.

- The PM collection rate per hour varied from site to site (depending on pollution load) and capacity of devices (flow rate of $1250 \mathrm{~m}^{3} \mathrm{~h}^{-1}$ and 2500 $\mathrm{m}^{3} \mathrm{~h}^{-1}$ ) and found in the range of $0.15 \mathrm{~g} \mathrm{~h}^{-1}$ at ITO to $0.49 \mathrm{~g} \mathrm{~h}^{-1}$ at Anand Vihar.

- The same design and capacity of the device perform differently at a different site, which might be due to different particle size distribution. The distribution of particle size depends on the contribution of sources at a particular site.

- The study recommended that there is a need to scaleup of the technology with high throughput to enhance the zone of influence.
- The filter materials need to be improved so that the efficiency of removal of an ultrafine and finer particle can be improved.

- Operation and maintenance of devices in the field are one of the major challenges, especially protection from rain, which can be upgraded through automation of the device.

- In view of the heterogeneity of spatial distribution of pollution levels within city, there is a need to identify such hotspot areas and install more such devices to reduce the exposure to the common public.

Supplementary Information The online version contains supplementary material available at https://doi.org/10.1007/ s13762-021-03641-3.

Acknowledgements Authors acknowledge the role of the Central Pollution Control Board, New Delhi, for funding and technically supporting the project titled "Deployment and Performance Evaluation of Air Purification Unit for Traffic Junction Air Pollution Abatement Plan in Delhi." The authors would also like to acknowledge the funding support from the Department of Science and Technology Delhi, India,

Authors' contribution SG was involved in original writing, methodology and data analysis; SK helped in review and editing; SM contributed to data collection and sorting, data analysis, RT helped in writing and data analysis; SKG was involved in review \& edit, PG helped in review; RK contributed to concept and guidance. 


\section{Declarations}

Conflict of interest The authors declare no conflict of interest.

\section{References}

Amann M, Purohit P, Bhanarkar AD, Bertok I, Borken-Kleefeld J, Cofala $\mathbf{J}$ et al (2017) Managing future air quality in megacities: a case study for Delhi. Atmos Environ 161:99-111. https://doi.org/10.1016/j.atmosenv.2017.04.041

Balakrishnan, K., Dey, S., Gupta, T., Dhaliwal, R. S., Brauer, M., \& Cohen, A. J. (2019). India State-Level Disease Burden Initiative Air Pollution Collaborators. The impact of air pollution on deaths, disease burden, and life expectancy across the states of India: the Global Burden of Disease Study 2017. Lancet Planet Health, 3(01), e26-e39. https://doi.org/10.1016/S25425196(18)30261-4

Census, 2011. Demographic Profile of Delhi. Available at https:// censusindia.gov.in/2011-common/censusdata2011.html visited on $21 / 7 / 2020$

CPCB (2010) Air quality monitoring, emission inventory and source apportionment study for Indian Cities, New Delhi

CPCB (2018) WAYU, the air filter device that will make sure the people of Delhi get to breathe fresh air. Central Pollution Control Board, Government of India, New Delhi. http:// www.cpcbenvis.nic.in/news/TCI\%2027\%20sep\%202018.pdf Accessed 01 April 2021

Dholakia HH, Purohit P, Rao S, Garg A (2013) Impact of current policies on future air quality and health outcomes in Delhi, India. Atmos Environ 75:241-248. https://doi.org/10.1016/j. atmosenv.2013.04.052

Gokhale S, Khare M (2007) Statistical behavior of carbon monoxide from vehicular exhausts in urban environments. Environ Model Softw 22(4):526-535. https://doi.org/10.1016/j.envso ft.2006.02.008

Goyal P, Gulia S, Goyal SK, Kumar R (2019) Assessment of the effectiveness of policy interventions for Air Quality Control Regions in Delhi city. Environ Sci Pollut Res 26(30):3096730979. https://doi.org/10.1007/s11356-019-06236-1

GRIMM (2020) PM Monitor. https://www.grimm-aerosol.com/ products-en/environmental-dust-monitoring/handheld-pmmonitor/11-d/ Accessed on 27 March 2020

Gulia S, Nagendra SS, Khare M, Khanna I (2015) Urban air quality management-a review. Atmos Pollut Res 6(2):286-304. https://doi.org/10.5094/APR.2015.033

Gulia S, Nagendra SS, Khare M (2017) A system based approach to develop hybrid model predicting extreme urban NOx and PM2.5 concentrations. Transp Res Part D Transp Environ 56:141-154. https://doi.org/10.1016/j.trd.2017.08.005

Gulia S, Goyal P, Goyal SK, Kumar R (2019) Re-suspension of road dust: contribution, assessment and control through dust suppressants-a review. Int J Environ Sci Technol 16(3):17171728. https://doi.org/10.1007/s13762-018-2001-7

Gulia S, Tiwari R, Mendiratta S, Kaur S, Goyal SK, Kumar R (2020) Review of scientific technology-based solutions for vehicular pollution control. Clean Technol Environ Policy. https://doi.org/10.1007/s10098-020-01952-6

Gupta I, Kumar R (2006) Trends of particulate matter in four cities in India. Atmos Environ 40(14):2552-2566. https://doi.org/10. 1016/j.atmosenv.2005.12.021

Gupta I, Salunkhe A, Kumar R (2010) Modelling 10-year trends of $\mathrm{PM}_{10}$ and related toxic heavy metal concentrations in four cities in India. J Hazard Mater 179(1-3):1084-1095. https:// doi.org/10.1016/j.jhazmat.2010.03.117

Gurjar BR, Ravindra K, Nagpure AS (2016) Air pollution trends over Indian megacities and their local-to-global implications. Atmos Environ 142:475-495. https://doi.org/10.1016/j.atmos env.2016.06.030

Guttikunda SK, Goel R (2013) Health impacts of particulate pollution in a megacity-Delhi, India. Environ Dev 6:8-20. https:// doi.org/10.1016/j.envdev.2012.12.002

Guttikunda SK, Gurjar BR (2012) Role of meteorology in seasonality of air pollution in megacity Delhi, India. Environ Monitor Assess 184(5):3199-3211. https://doi.org/10.1007/ s10661-011-2182-8

Heal MR, Kumar P, Harrison RM (2012) Particles, air quality, policy and health. Chem Soc Rev 41(19):6606-6630. https:// doi.org/10.1039/C2CS35076A

Jain S, Sharma T (2020) Social and travel lockdown impact considering coronavirus disease (COVID-19) on air quality in megacities of India: present benefits, future challenges and way forward. Aerosol Air Qual Res 20:1222-1236. https:// doi.org/10.4209/aaqr.2020.04.0171

Januszkiewicz K, Kowalski KG (2019) Air purification in highlyurbanized areas with the use of $\mathrm{TiO}_{2}$. New approach in designing urban public space with beneficial human condition. In IOP conference series: materials science and engineering, vol 603, no 3. IOP Publishing, p 032100. https://doi.org/10. 1088/1757-899X/603/5/052071

Kumar P, Gulia S, Harrison RM, Khare M (2017) The influence of odd-even car trial on fine and coarse particles in Delhi. Environ Pollut 225:20-30. https://doi.org/10.1016/j.envpol. 2017.03.017

Kumar P, Hama S, Omidvarborna H, Sharma A, Sahani J, Abhijith KV et al (2020) Temporary reduction in fine particulate matter due to 'anthropogenic emissions switch-off'during COVID-19 lockdown in Indian cities. Sustain Cities Soc. https://doi.org/ 10.1016/j.scs.2020.102382

Lancet Planet Health, 2019. The impact of air pollution on deaths, disease burden, and life expectancy across the states of India: the Global Burden of Disease Study 2017. 26-39. https://doi. org/10.1016/S2542-5196(18)30261-4

Mathew J, Goyal R, Taneja KK, Arora N (2015) Air pollution and respiratory health of school children in industrial, commercial and residential areas of Delhi. Air Qual Atmos Health 8(4):421-427. https://doi.org/10.1007/s11869-014-0299-y

Mishra N, Devi S, Jakhmola BK (2018) A study on determination of metals in road side dust at selected locations of Delhi. Int J Eng Sci Invent (IJESI) 7:01-15

MoSPI (Ministry of Statistics and Program Implementation) 2018. MOTOR VEHICLES - Statistical Year Book India 2018. http:// mospi.nic.in/statistical-year-book-india/2018/189 visited on $15 / 8 / 2020$ 
Sharma M, Dikshit O (2015) Comprehensive Study on Air Pollution and Green House Gases (GHGS) in Delhi (Draft Report). Government National Capital Territory of Delhi, New Delhi 266

Sharma S, Zhang M, Gao J, Zhang H, Kota SH (2020) Effect of restricted emissions during COVID-19 on air quality in India. Sci Total Environ 728:138878. https://doi.org/10.1016/j.scito tenv. 2020.138878

TERI (The Energy Resources Institute) (2018). Source apportionment of PM2.5 and PM10 of Delhi NCR for identification of major sources. Joint report by ARAI and TERI. 560 Pages. Available on https://www.teriin.org/sites/default/files/201808/Report_SA_AQM-Delhi-NCR_0.pdf. Visited on 15/8/2020

World Health Organization (2006) Air quality guidelines: global update 2005: particulate matter, ozone, nitrogen dioxide, and sulfur dioxide. World Health Organization, Geneva

WHO. World Health Organization; Geneva: 2018. WHO global ambient air quality database. http://www.who.int/airpolluti on/data/cities/en/ 